\title{
Аналіз лікування ускладнених дивертикулів дистальних відділів шлунково-кишкового тракту
}

\begin{abstract}
Мета роботи: проаналізувати досвід лікування хворих з ускладненими дивертикулами товстої кишки, в тому числі з використанням лапароскопії і ендоскопічної техніки для удосконалення та вибору належної діагностично-лікувальної тактики при даній патології.

Матеріали і методи. Проведено аналіз результатів лікування 121 хворого за період з 2008 до 2021 р. госпіталізованих ургентно при ускладненнях дивертикулярної хвороби, які виникли: товстокишкова кровотеча - у 60 хворих, дивертикуліт - у 9, перфорація дивертикула - у 19, дивертикулярний інфільтрат - у 18, а у 15 хворих було поєднання: дивертикуліт та дивертикулярний абсцес - у 6, дивертикуліт та перитоніт - у 4, дивертикуліт із динамічною кишковою непрохідністю - у 5. Хворим застосовували стандартний діагностично-лікувальний алгоритм.

Результати досліджень та їх обговорення. В групі хворих із клінікою товстокишкової кровотечі (60) при неефективності гемостатичної терапії у 7 пацієнтів в ургентному порядку було виконано резекцію ураженого сегмента товстої кишки з кровоточивими дивертикулами в об’ємі лівобічної геміколектомії (6) та резекції сигмоподібної кишки (1) з формуванням анастомозу “кінець в кінець”. У групі хворих із запальними ускладненнями дивертикулярної хвороби неперфоративного генезу (42) розпочинали консерватине загальне та місцеве лікування. Прооперовано 6 хворих, у яких спостерігали прогресування інфільтрату та абсцедування: резекція сегмента товстої кишки з дивертикулярним абсцесом із виведенням кінцевої стоми. В групі з перфоративним дивертикулітом (19) всі хворі були в ургентному порядку прооперовані. Післяопераційної летальності не спостерігали. У хворих, яким застосовували лапароскопічні методи діагностики та лікування, післяопераційних ускладнень з боку післяопераційної рани не спостерігали.

Таким чином, найпоширенішими ускладненнями дивертикулярної хвороби є запальні ускладнення та кровотеча, лікування яких переважно консервативне. Лікувальна тактика при запальних ускладненнях дивертикулів диференційована: спочатку консервативна з місцевою протизапальною терапією, а при ускладненні перфорацією - хірургічна з можливим застосуванням малоінвазивних лапароскопічних методів лікування.
\end{abstract}

Ключові слова: дивертикули товстої кишки; діагностично-лікувальна тактика.

Постановка проблеми і аналіз останніх досліджень та публікацій. Дивертикули шлунково-кишкового тракту являють собою випинання стінки кишкової трубки та можуть розміщуватися на всьому її протязі, супроводжуються різноманітними клінічними проявами та ускладненнями. Можуть бути поодинокими та множинними, справжніми та несправжніми, ускладненими та неускладненими. За локалізацією існують дивертикули стравоходу, дванадцятипалої кишки (окремо - парапапілярні), тонкої кишки (голодної, клубової, зокрема, так званий дивертикул Мекеля), товстої кишки. Ускладненнями дивертикулів можуть бути: дивертикуліт, кровотеча, перфорація, параколярний інфільтрат, абсцеси, медіастиніт, перитоніт, нориці, непрохідність, малігнізація та ін. [2].

Найпоширенішими $є$ дивертикули товстої кишки, які у 84 \% діагностують у лівих іiї відділах, а саме у низхідній ободовій та сигмоподібній кишці. Дивертикули являють собою грижові випинання слизової та підслизової через слабкі місця. Виникнення їх пов’язують з особливостями харчування, віковими змінами кишки, дисплазією сполучної тканини та іншими чинниками $[3,8]$. У своїй практичній діяльності хірурги переважно стикаються з ускладненнями дивертикулярної хвороби, які діагностують у 5 \% таких хворих та $є$ 5 \% ускладнень серед всієї невідкладної хірургічної патології органів черевної порожнини $[1,9]$, а у хворих похилого та старечого віку ускладнення спостерігають до 60 \% випадків. Летальність при ускладнених дивертикулах шлунково-кишкового тракту сягає до $10 \%$ [5, 10]. Тому питання діагностики та лікування ускладнених дивертикулів шлунково-кишкового тракту залишаються на сьогодні невирішеною проблемою [6-8].

Мета роботи: аналіз досвіду лікування хворих із ускладненими дивертикулами товстої кишки, в тому числі з використанням лапароскопії та ендоскопічної техніки для удосконалення та вибору належної діагностично-лікувальної тактики при даній патології.

Матеріали і методи. Проведено аналіз результатів лікування 121 хворого, які перебували на стаціонарному лікуванні у Клінічному високо- 


\section{З ДОСВІДУ РОБОТИ}

спеціалізованому хірургічному Центрі з малоінвазивними технологіями КНП “ВОКЛ ім. М. І. Пирогова” та у відділеннях клінік абдомінальної та малоінвазивної хірургії Військово-медичного клінічного центру Центрального регіону з ускладненнями дивертикулів товстої кишки за період 3 2008 до 2021 р. Серед пацієнтів чоловіків було 46 (38,02 \%), жінок - 75 (61,98 \%), вік хворих - від 16 до 72 років. При розподілі за віком хворих від 40 до 59 років було 29, від 60 до 69 років - 29, старше 70 років - 63. Середній вік хворих становив 66,1 $\pm 2,5$ року. Анамнестично клінічні прояви захворювання встановлено впродовж 6-ти місяців до госпіталізації в 71,9 \% хворих, а у 28,1 \% - більше 6 місяців.

У нашому дослідженні всіх хворих із дивертикулами товстої кишки госпіталізували в ургентному порядку.

При госпіталізації хворим проводили діагностично-лікувальний алгоритм згідно з протоколами надання невідкладної медичної допомоги: проведення повного клініко-лабораторного обстеження, оглядової рентгенографії органів черевної порожнини, грудної порожнини, ультрасонографії, ургентної спіральної комп’ютерної томографії органів черевної порожнини і малого таза з подвійним контрастуванням, фіброезофагогастродуоденоскопії, при неможливості виключити невідкладну хірургічну патологію (перфорацію порожнистого органа, перитоніт) - діагностичної лапароскопії. При відсутності клініки перитоніту - після відповідної підготовки кишечника виконували фіброколоноскопію та при відсутності можливостей виконання останньої - іригографію.

При фізикальному та інструментальному дообстеженні було встановлено такі види ускладнень: товстокишкова кровотеча - у 60 (49,59 \%) хворих, дивертикуліт - у 9 (7,43 \%), перфорація дивертикула - у 19 (15,70 \%), дивертикулярний інфільтрат - у 18 (14,88 \%), а у 15 хворих було поєднання: дивертикуліт та дивертикулярний абсцес - у 6 (4,96 \%), дивертикуліт та перитоніт - у 4 (3,31 \%), дивертикуліт із динамічною кишковою непрохідністю - у 5 (4,13 \%).

За поширенням дивертикули локалізувалися у лівих відділах ободової кишки - низхідній ободовій (13), сигмоподібній кишці (68 хворих), низхідній ободовій та сигмоподібній (30), правих відділах (2), за ходом усієї товстої кишки (8) та ін.

Хворі, госпіталізовані з клінікою товстокишкової кровотечі з виділеннями, здебільшого крові темного (вишневого) кольору з наявністю згортків, підлягали проведенню консервативного лікування, яке включало комплексну гемостатичну, противиразкову, інфузійну, антибактерійну терапію з подальшим дообстеженням - підготовкою та виконанням фіброколоноскопії. Після чого визначали подальшу тактику.

Хворі, госпіталізовані з запальними ускладненнями дивертикулярної хвороби, підлягали ургентному дообстеженню: оглядовій рентгенографії органів черевної порожнини, ультрасонографії - в усіх випадках, спіральній комп'ютерній томографії (СКТ), лапароцентезу та діагностичній лапароскопії - при нез'ясованій клінічній картині. Застосування СКТ у 50,41 \% хворих із подвійним контрастуванням дає змогу точно виявити локалізацію дивертикулярного інфільтрату, його розміри, поширеність, виразність морфологічних змін у ньому та навколишніх тканинах та наявність інших ускладнень дивертикулярної хвороби.

У даній групі хворих для визначення поширення запального процесу при гострих запальних ускладненнях застосовували класифікацію Хінчі: I стадія - периколічний абсцес чи інфільтрат, II стадія - тазовий, внутрішньочеревний чи ретроперитонеальний абсцес, III стадія - генералізований гнійний перитоніт, IV стадія - генералізований каловий перитоніт. Клінічні прояви включали: біль у лівій здухвинній ділянці, а іноді і по лівому фланку, гіпогастрії, загальну слабість, сухість у роті - в 73 хворих; підвищення температури тіла до фебрильних значень, лейкоцитоз - у 21 хворого, здуття живота, нудоту, часті рідкі випорожнення у 37 хворих, наявність в черевній порожнині при пальпації пухлиноподібного утворення без чітких контурів - у 21 хворого. Клініка перфоративного дивертикуліту в 19 випадках нічим не відрізнялась від клініки перфорації порожнистого органа.

\section{Результати досліджень та їх обговорення.} У групі хворих із клінікою товстокишкової кровотечі - 60 хворих - лікування розпочинали 3 проведення комплексної консервативної гемостатичної терапії, спрямованої на зупинку кровотечі та стабілізацію гемодинамічних показників. Особливості діагностики дивертикульозу, ускладненого товстокишковою кровотечею, характеризується труднощами. Окрім клінічних ознак кровотечі (виділення крові зі випорожненнями вишневого кольору), змін гемодинаміки, неможливо чітко відразу встановити джерело кровотечі. За даними окремих авторів, невідкладна фіброколоноскопія інформативна лише у 15 \% випадків [7]. Саме це вимагає спочатку проведення інтенсивної гемостатичної, інфузійної консервативної терапії з метою стабілізації стану хворого та подальшої належної підготовки шлунково-кишкового тракту. 
Після виконання фіброколоноскопії встановлювали локалізацію дивертикулів - джерело кровотечі, стан гемостазу. Після дообстеження та виявлення активно триваючої кровотечі і відсутності ефекту від консервативного лікування хворі підлягали проведенню оперативного лікування. У 7 пацієнтів в ургентному порядку було виконано резекцію ураженого сегмента товстої кишки 3 кровоточивими дивертикулами в об'ємі лівобічної геміколектомії (6) та резекції сигмоподібної кишки (1) 3 формуванням анастомозу “кінець в кінець”.

У групі хворих із запальними ускладненнями дивертикулярної хвороби неперфоративного генезу - 42 хворі - лікування також було консервативним. Воно включало проведення спазмолітичної, антибактеріальної, протизапальної (диклофенак) інфузійної терапії, застосування пробіотиків та відповідної дієтотерапії. При проведенні антибактеріальної терапії перевагу віддавали цефалоспоринам III покоління, фторхінолонам та метронідазолу (цефтріаксон чи цефуроксим+ципрофлоксацин+метронідазол). Місцеве лікування полягало у призначенні фізіотерапевтичних методів та компресів на ділянку інфільтрату 3 димексидом та антибіотиками. У 6 хворих із даної групи консервативна терапія була неефективною, що клінічно та за даними ультрасонографії і спіральної комп’ютерної томографії проявлялося прогресуванням інфільтрату та абсцедуванням, та вимагало проведення операційних втручань: резекції сегмента товстої кишки з дивертикулярним абсцесом із виведенням кінцевої стоми.

У групі хворих із перфоративним дивертикулітом - 19 хворих - лікування передбачало проведення ургентного операційного втручання в терміни від 2 до 4 годин. Інтраопераційно було виявлено перфорацію дивертикулу сигмоподібної кишки - в 14 випадках, низхідної ободової - у 5 хворих. У 9 випадках був обмежений перитоніт, у -2 абсцес порожнини малого таза, у 4 - гнійний перитоніт, у 4 каловий перитоніт. Варіанти операційних втручань: лапаротомія, резекція ураженого сегмента сигмоподібної кишки з формуванням кінцевої сигмостоми, санація і дренування черевної порожнини - у 11 хворих; лапаротомія, лівобічна геміколектомія 3 виведенням кінцевої стоми, санація і дренування черевної порожнини - у 5 хворих; лапароскопія з виведенням перфорованого дивертикулу у вигляді підвісної колостоми, санація і дренування черевної порожнини - у 3 хворих. Післяопераційний період включав проведення інтенсивної антибактерійної, протизапальної, антисекреторної, антикоагулянтної, інфузійної терапії.
Післяопераційної летальності не було. У невеликої кількості пацієнтів мали місце післяопераційні ускладнення, такі як: нагноєння післяопераційної рани (6 хворих) та деякі парастомальні ускладнення у вигляді евентерації - у 2, парастомального абсцесу - у 2, лігатурних нориць - в 1, арозивної кровотечі - 1 хворого. У хворих, яким застосовувалися лапароскопічні методи діагностики та лікування, післяопераційних ускладнень 3 боку післяопераційної рани не спостерігали.

Таким чином, у групі хворих із клінікою товстокишкової кровотечі тактика зрозуміла та полягає у призначенні інтенсивної консервативної гемостатичної терапії з подальшим дообстеженням - фіброколоноскопією та визначенням показань до операційного лікування. При гострому дивертикуліті немає єдиної та визначеної на сьогодні тактики лікування. Тому згідно з класифікацією Хінчі при I та II стадії вважаємо за потрібне призначення консервативної терапії з місцевою протизапальною терапією та за показаннями - діагностичною лапароскопією та постановкою внутрішньочеревного дренажа, а при III та IV стадіях показане операційне лікування - лапаротомія з інтраопераційним визначенням подальшої тактики.

Висновки. 1. Дивертикулярна хвороба товстої кишки є захворюванням, для якого характерний безсимптомний перебіг, велика кількість ускладнень, які виявляються у старшому віці (переважно 70-79 років). Частіше хворіють жінки. Частота дивертикульозу в структурі захворювань, з якими зверталися пацієнти до хірургічного стаціонару - 1,56 \%.

2. Найчастіше поширеними ускладненнями дивертикулярної хвороби є дивертикуліт (62,0%) і кровотеча (49,59 \%), лікування яких переважно консервативне.

3. Найчутливий та специфічний метод інструментальної діагностики, який дає змогу підвищити раннє виявлення захворювання та його ускладнень, є спіральна комп’ютерна томографія з подвійним контрастуванням.

4. Лікувальна тактика при запальних ускладненнях дивертикулів переважно консервативна 3 місцевою протизапальною терапією, а при ускладненні перфорацією - хірургічна із можливим застосуванням малоінвазивних лапароскопічних методів лікування.

Перспективи подальших досліджень. У подальшому передбачено дослідити причини та фактори ризику виникнення дивертикулів товстої киши, а також ультраструктурні зміни стінки самого дивертикулу. 


\section{З ДОСВІДУ РОБОТИ}

\section{СПИСОК ЛІТЕРАТУРИ}

1. Вибір лікувально-діагностичних заходів при гострому дивертикуліті товстого кишечника з розвитком місцевих ускладнень запального характеру / В. В. Міщенко, П. І. Пустовойт, Р. Ю. Вододюк, В. В. Величко // Харківська хірургічна школа. - 2021. - № 1 (106). - С. 85-91.

2. Дивертикулярная болезнь толстой кишки / А. А. Свистунов, М. А. Осадчук, Н. В. Криеева, А. М. Золотовицкая // Клиническая медицина. - 2018. - № 96 (6). - С. 498-505.

3. Клинические рекомендации по диагностике и лечению взрослых пациентов дивертикулярной болезнью ободочной кишки / за ред. Ю. А. Шелыгина. Москва, 2013. - 22 с.

4. Помазкин В. И. Отдаленные результаты оперативного лечения дивертикулярной болезни толстой кишки / В. И. Помазкин, В. В. Ходаков // Вестник хирургии им. И. И. Грекова. - 2016. - № 175 (2). - С. 101-104.

5. Шелыгин Ю. А. Лапароскопический доступ при плановом хирургическом лечении дивертикулярной болезни / Ю. А. Шелыгин, С. И. Ачкасов, А. И. Москалев // Колопроктология. - 2014. - № 4 (50). - С. 5-13.

\section{REFFERENCES}

1. Mishchenko, V.V., Pustovoit, P.I., Vododiuk, R.Yu., \& Velychko, V.V. (2021). Vybir likuvalno-diahnostychnykh zakhodiv pry hostromu dyvertykuliti tovstoho kyshechnyka z rozvytkom mistsevykh uskladnen zapalnoho kharakteru [The choice of treatment and diagnostic measures for acute diverticulitis of the colon with the development of local inflammatory complications]. Kharkivska khirurhichna shkola - Kharkiv Surgical School, 1 (106), 85-91 [in Ukrainian].

2. Svystunov, A.A., Osadchuk, M.A., Kryeeva, N.V., \& Zolotovytskaia, A.M. (2018). Dyvertykuliarnaia bolezn tolstoi kyshky [Diverticular disease of the colon]. Klynycheskaia medytsyna Clinical Medicine, 96 (6), 498-505 [in Russian].

3. Shelyhin, Yu.A. (2013). Klinicheskie rekomendatsii po diagnostike i lecheniyu vzroslyh patsientov divertikulyarnoy boleznyu obodochnoy kishki [Clinical practice guidelines for the diagnosis and treatment of adult patients with diverticular colon disease]. Моsсщца [in Russian].

4. Pomazkin, V.I., \& Hodakov, V.V. (2016). Otdalennye rezultaty operativnogo lecheniya divertikulyarnoy bolezni tolstoy kishki [Long-term results of surgical treatment of diverticular disease of the colon]. Vestnik hirurpii im. I. I. Prekova - Bulletin of Surgery named after I. I. Prekov, 175 (2), 101-104 [in Russian]. 5. Shelyigin, Yu.A., Achkasov, S.I., \& Moskalev, A.I. (2014). Laparoskopicheskiy dostup pri planovom hirurgicheskom lechenii
6. Colonoscopy after Hinchey I and II left-sided diverticulitis: utility or futility? / A. S. Walker, J. R. Bingham, K. M. Janssen [et al.] // Am. J. Surg. - 2016. - Vol. 212 (5). - P. 837-843.

7. Current management of patients with diverticulosis and diverticular disease: a survey from the 2-nd Internatioanl Symposium in Diverticular Diaease / A. Tursi, M. Picchio, W. Elisei [et al.] // J. Clin. Gastroentarol. - 2016. - Vol. 50 (2). - P. 97-100.

8. Hand-assisted laparoscopic vs open colectomy: an assessment from the American College of Surgeons National Surgical Quality Improvement Program procedure-targeted cohort / C. Benlice, M. Costedio, L. Stocchi [et al.] // Am. J. Surg. - 2016. - Vol. 212 (2). - P. 808-813.

9. Laparoscopic lavage vs primary resection for acute perforated diverticulitis / J. K. Schultz, S. Yaqub, S. Wallon // JAMA. - 2015. - Vol. 314 (13). - P. 1364-1375.

10. Medically treated diverticular abscess associated with high risk of recurrence and disease complications / B. Devaraj, W. Liu, J. Tatum [et al.] // Dis. Colon. Rectum. - 2016. - Vol. 59 (3). P. 208-215.

divertikulyarnoy bolezni [Laparoscopic approach for planned surgical treatment of diverticular disease]. Koloproktologiya - Coloproctology, 4 (50), 5-13 [in Russian].

6. Walker, A.S, Bingham, J.R, \& Janssen, K.M. (2016). Colonoscopy after Hinchey I and II left-sided diverticulitis: utility or futility? Am. J. Surg., 212 (5), 837-843.

7. Tursi, A., Picchio, M., Elisei, W., Di Mario F., Scarpignato, C., \& Brandimarte, G. (2016). Current management of patients with diverticulosis and diverticular disease: a survey from the 2-nd International Symposium in Diverticular Diaease. J. Clin. Gastroentarol., 50 (2), 97-100.

8. Benlice, C., Costedio, M., Stocchi, L., Abbas, M.A., \& Gorgun, E. (2016). Hand-assisted laparoscopic vs open colectomy: an assessment from the American College of Surgeons National Surgical Quality Improvement Program procedure-targeted cohort. Am. J. Surg., 212, 808-813.

9. Schultz, J.K., Yaqub, S., Wallon S, Blecic, L., Forsmo, H.M., Folkesson, J., ... Øresland, T. (2015). Laparoscopic lavage vs primary resection for acute perforated diverticulitis. JAMA, 314 (13), 1364-1375.

10. Devaraj, B., Liu, W., Tatum, J., Cologne, K., \& Kaiser, A.M. (2016) Medically treated diverticular abscess associated with high risk of recurrence and disease complications. Dis. Colon. Rectum., 59 (3), 208-221.

Отримано 07.09.2021 
V. O. SHAPRYNSKYI, Y. V. SHAPRYNSKYI, A. V. VERBA, V. A. KOROBKO, V. F. BILOSHCHYTSKYI, S. S. STUKAN, D. V. MIKHURINSKYI

National Pirogov Memorial Medical University, Vinnytsia

\section{TREATMENT ANALYSIS OF COMPLICATED DIVERTICULA OF THE DISTAL PARTS OF THE GASTROINTESTINAL TRACT}

The aim of the work: to analyze the experience of treatment of patients with complicated diverticula of the colon, including laparoscopy and endoscopic techniques to improve and select appropriate diagnostic and treatment tactics for this pathology.

Materials and Methods. Analysis of treatment results of 121 patients who had been hospitalized in urgently way in the period from 2008 to 2021 with complications of diverticular disease was performed. There were: colon bleeding - in 60 patients, diverticulitis - in 9, perforation of the diverticulum - in 19, diverticular infiltrate - in 18. 15 patients had combination: diverticulitis and diverticular abscess - in 6 , diverticulitis and peritonitis - in 4, diverticulitis with dynamic intestinal obstruction - in 5. Standard diagnostic and treatment algorithm were used.

Results and Discussion. In the group of patients with the clinical picture of colon bleeding (60) with ineffective hemostatic therapy in 7 patients we urgently performed resection of the affected segment of the colon with bleeding diverticula (left hemicolectomy (6)) and resection of the sigmoid colon (1) with end to end anastomosis. In the group of patients with inflammatory complications of diverticular disease without perforating (42) conservative general and local treatment was started. 6 patients with complication such as abscess underwent surgery. We perfomed resection of the segment of the colon with diverticular abscess and we formed terminal stoma. In the group with perforated diverticulitis (19) all patients were urgently operated. Postoperative mortality was not observed. It was not any postoperative complications from the postoperative wound in patients who underwent laparoscopic methods of diagnosis and treatment.

Consequently, the most common complications of diverticular disease are inflammatory complications and bleeding, the treatment of which is mostly conservative. Treatment tactics for inflammatory complications of diverticula is different: initially conservative with local antiinflammatory therapy, and for complications with perforation - surgical with the possible minimally invasive laparoscopic method.

Key words: diverticula of the colon; diagnostic and treatment tactics. 